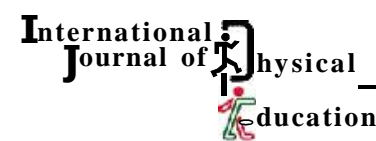

DOI : 10.15740/HAS/IJPE/8.1/28-31

Volume 8 | Issue 1 | April, 2015 | 28-31

e ISSN-0976-7924 $\square$ Visit us : www.researchjournal.co.in

Research Paper

\title{
Effect of resistance training on passing ability of basketball players
}

-JOJI VARGHEESE AND P.V. SHELVAM ${ }^{1}$

Received : 04.12.2014; Revised : 02.03.2015; Accepted : 15.03 .2015

Members of the Research Forum

Associated Authors:

${ }^{1}$ Department of Physical Education

and Sports Sciences, Annamalai

University, ANNAMALAINAGAR

(T.N.) INDIA

Email: selvamvsdrn@gmail.com

Author for correspondence :

JOJI VARGHEESE

Mar Baselios College of Engineering and Technology,

THIRUVANANTHAPURAM

(KERALA) INDIA

Email: iamjoji2000@gmail.com

\section{-ABSTRACT}

The purpose of the study was to find out the effect of resistance training on passing ability among college basketball players. To achieve this purpose of the study, thirty college students were selected as subjects who were from Trivandrum. The selected subjects were aged between 18 to 22 years. They were divided into two equal groups of fifteen each, Group I underwent resistance training and Group II acted as control that did not participate in any special training apart from their regular curricular activities. The subjects were tested on selected criterion variable such as shooting performance prior to and immediately after the training period. The selected criterion variable such as passing ability was determined through wall passing test. The analysis of covariance (ANCOVA) was used to find out the significant differences if any, between the experimental group and control group on selected criterion variable. In all the cases, 0.05 level of confidence was fixed to test the significance, which was considered as an appropriate. The result of the present study has revealed that there was a significant difference among the experimental and control group on passing ability.

- KEY WORDS : Resistance training, Basketball, Passing ability

- HOW TO CITE THIS PAPER : Vargheese, Joji and Shelvam, P.V. (2015). Effect of resistance training on passing ability of basketball players. Internat. J. Phy. Edu., 8 (1) : 28-31. 